\title{
Perlindungan Hukum Terhadap Korban Kekerasan Seksual Dalam Rangka Mewujudkan Keadilan Restoratif
}

\author{
Hadibah Zachra Wadjo, ${ }^{1, *}$ Judy Marria Saimima ${ }^{2}$ \\ ${ }^{1,2}$ Fakultas Hukum Universitas Pattimura \\ dibawadjo123@gmail.com ${ }^{1}$; judymarria@gmail.com ${ }^{2}$ \\ * Corespondence Author
}

\begin{abstract}
Abstrak
Perlindungan hukum sangatlah penting dan berpengaruh terhadap keadilan bagi seluruh warga Negara Indonesia. Menurut pandangan konsep restorative justice penanganan kejahatan yang terjadi bukan hanya menjadi tanggung jawab negara akan tetapi juga merupakan tanggung jawab masyarakat. Oleh karena itu konsep restorative justice dibangun berdasarkan pengertian bahwa kejahatan yang telah menimbulkan kerugian harus dipulihkan kembali baik kerugian yang diderita oleh korban maupun kerugian yang ditanggung oleh masyarakat. Beragam persoalan sensitif menimpa kehidupan kaum perempuan, antaranya kejahatan kekerasan seksual (sexual violence) dan pelecehan seksual (sexual harassment). Perempuan sangat rentan menjadi korban kejahatan (victim of crime) di bidang kesusilaan. Perlindungan adalah betuk dari salah satu tindakan untuk mencegah terjadinya penindasan terhadap perempuan secara berkepanjangan. Upaya lembaga perlindungan hukum atau lembaga advokasi dalam menciptakan penegakan hukum yang baik sangat membutuhkan faktor- faktor penunjang agar terciptanya perlindungan hukum tersebut dengan baik dan efektif.
\end{abstract}

\section{Kata kunci: Perlindungan Hukum, Kekerasan, Keadilan}

Naskah dikirim: 19 Juli 2020|Direvisi : 13 Agustus 2020|Diterbitkan: 27 Agustus 2020 


\begin{abstract}
Legal protection is very important and affects justice for all Indonesian citizens. According to the viewpoint of the concept of restorative justice, handling crimes that occur is not only the responsibility of the state but also the responsibility of the community. Therefore, the concept of restorative justice is built based on the notion that crimes that have caused losses must be recovered, both losses suffered by the victim and losses borne by the community. Various sensitive issues afflict the lives of women, including crimes of sexual violence (sexual violence) and sexual harassment (sexual harassment). Women are very vulnerable to becoming victims of crime in the field of decency. The efforts of legal protection agencies or advocacy institutions in creating good law enforcement really need supporting factors in order to create such legal protection properly and effectively.
\end{abstract}

\title{
Keywords: Legal Protection, Violence, Justice
}

\section{Pendahuluan}

Hukum memiliki fungsi sebagai pelindung kepentingan manusia, agar kepentingan manusia terlindungi, hukum harus dilaksanakan secara profesional. Pelaksanaan hukum dapat berlangsung normal, damai, dan tertib. Perlindungan hukum sangatlah penting dan berpengaruh terhadap keadilan bagi seluruh warga Negara Indonesia. Berdasarkan ketentuan dalam Undang-undang Dasar Negara Republik Indonesia Tahun 1945 pasal 1 ayat 3, "Negara Indonesia adalah negara hukum". ${ }^{1}$ Oleh karena itu, segala kehidupan kenegaraan selalu berdasarkan kepada hukum.

Perlindungan hukum adalah penyempitan arti dari perlindungan khusus terhadap hukum. Perlindungan yang diberikan oleh hukum, meliputi adanya hak dan kewajiban, ${ }^{2}$ dalam hal ini yang dimiliki oleh manusia sebagai subyek hukum dalam interaksinya

${ }^{1}$ Ubwarin, E. (2019). Penegakan Hukum Terhadap Pelaku Penyelundupan Penyu Di Kabupaten Kepulauan Aru. RESAM Jurnal Hukum , 1-20.

${ }^{2}$ Sumirat, I. R. (2017). Perlindungan Hukum Terhadap Perempuan dan Anak Korban Kejahatan Perdagangan Manusia. Jurnal Studi Gender Dan Anak, 3(01), 19-30.

DOI : $\underline{\text { https://doi.org/10.30598/belovol6issue1page48-59 }}$ 
dengan sesama manusia serta lingkungannya sebagai subyek hukum manusia memiliki hak dan kewajiban untuk melakukan suatu tindakan hukum. Jadi, setiap perbuatan manusia tanpa terkecuali diatur oleh hukum. ${ }^{3}$

Perbuatan pidana adalah perbuatan yang dilarang oleh suatu aturan hukum larangan mana disertai ancaman (sanksi) yang berupa pidana tertentu, bagi barang siapa melanggar larangan tersebut. Dapat juga dikatakan bahwa perbuatan pidana adalah perbuatan yang oleh suatu aturan hukum dilarang dan diancam pidana, asal saja dalam pada itu diingat bahwa larangan diajukan kepada perbuatan, (yaitu suatu keadaan atau kejadian yang ditimbulkan oleh kelakuan orang), sedangkan ancaman pidananya ditujukan kepada orang yang menimbulkannya kejadian itu. ${ }^{4}$

Kekerasan seksual sendiri merupakan suatu tindakan seksual secara fisik maupun non fisik oleh seseorang yang memiliki kekuasaan atas korban dengan tujuan memenuhi hasrat seksual pelaku yang tidak dikehendaki oleh korban. ${ }^{5}$ Menurut Komisi Nasional Anti kekerasan terhadap Perempuan (Komnas Perempuan), terdapat konsep moralitas terkait perempuan yang berkembang di tengah masyarakat. Perempuan dianggap sebagai simbol kesucian dan kehormatan. Konsep ini membuat perempuan seringkali dipandang sebagai aib kala mengalami tindak kekerasan seksual. ${ }^{6}$ Tidak hanya itu, perempuan pun sering menjadi pihak yang disalahkan atas tindakan tersebut. Hal ini pun, menjadi alasan banyak perempuan di Indonesia yang mengalami kekerasan seksual memilih bungkam.

\footnotetext{
${ }^{3}$ Rochaety, N. (2014). Menegakkan Ham Melalui Perlindungan Hukum Bagi Perempuan Korban Kekerasan Di Indonesia. PALASTREN Jurnal Studi Gender , 7 (1) 1-24.

${ }^{4}$ C.S.T. Kansil. (2014)Pokok-pokok Hukum Pidana. Jakarta. Pradnya Paramita. hal. 37

${ }^{5}$ Ekawati,dkk, Pembentukan Kelompok Anti Kekerasan Seksual Anak (KAKSA) Pada Komunitas Kader di Desa Sanur Kaja Denpasar, diakses pada 20 Mei 2020.

${ }^{6}$ Ayu Setyaningrum, R. A. (2019). Analisis Upaya Perlindungan dan Pemulihan Terhadap Korban Kekerasan dalam Rumah Tangga (KDRT) Khususnya Anak-Anak dan Perempuan. Jurnal Ilmiah Muqoddimah : Jurnal Ilmu Sosial, Politik, dan Humaniora , 3 (1) 1-21

DOI : https://doi.org/10.30598/belovol6issuelpage48-59 Copyright (c) 2020 Authors
} 
Ironisnya hal ini membuat kekerasan seksual menjadi sulit untuk diungkap dan ditangani dibandingkan bentuk kekerasan lainnya terhadap perempuan. ${ }^{7}$

Oleh sebab itu, dalam Pasal 1 angka 6 Undang-undang Nomor 11 Tahun 2012 tentang Sistem Peradilan Anak (UU SPPA) yang berbunyi sebagai berikut: "Keadilan restoratif adalah penyelesaian perkara tindak pidana dengan melibatkan pelaku, korban, keluarga pelaku/korban, dan pihak lain yang terkait untuk bersama-sama mencari penyelesaian yang adil dengan menekankan pemulihan kembali pada keadaan semula dan bukan pembalasan". Keadilan restoratif menawarkan sebuah pendekatan yang tujuannya mengurangi kejahatan dengan mengadakan pertemuan antara korban dan pelaku atau terdakwa serta memerlukan keterlibatan perwakilan masyarakat. Keadilan restoratif berbeda dengan keadilan retributif yang lebih mengedepankan pada pembalasan. Penerapan keadilan restibutif dianggap tidak lagi relevan, dan juga tidak menguntungkan bagi korban, bahkan yang ditemui adalah pelaku yang tidak jera sehingga melakukan perbuatan yang sama kembali.

Kekerasan seksual menimbulkan banyak akibat negatif apalagi jika korbannya adalah anak yang masih membutuhkan waktu untuk bertumbuh dan berkembang. Tindak kekerasan tersebut pasti akan sangat membekas dan meninggalkan efek yang lama baik secara fisik maupun secara mental. Bentuk-bentuk kekerasan seksual umumnya dilakukan dengan upaya memaksa dan keinginan salah satu pihak saja untuk merayu, mencolek, memeluk, meremas bagian tubuh, dan segala macam bentuk pelecehan lainnya hingga tujuan utamanya melakukan persetubuhan secara paksa. Kekerasan seksual dapat terjadi karena beberapa hal, mulai dari pola pengasuhan keluarga yang keliru, penyebaran pornografi di sosial media yang tidak terkontrol, hingga tidak adanya pendidikan seksual yang benar sejak dini. Hal ini membuat anak menjadi tidak mampu menyaring informasi yang seharusnya didapati sehingga anak cenderung berbuat salah. Berdasarkan hal

\footnotetext{
${ }^{7}$ Komnas Perempuan, (2015), 15 Bentuk Kekerasan Seksual Sebuah Pengenalan, Jakarta : Komnas Perempuan. hal.3

DOI : $\underline{\text { https://doi.org/10.30598/belovol6issue1page48-59 }}$ Copyright (c) 2020 Authors
} 
tersebut, maka diperlukan pengawasan dan bimbingan dari orang tua untuk mengarahkan anak agar mampu membedakan hal yang positif dan bermanfaat serta menjauhi hal negatif yang berbahaya.

Memberikan hukuman kepada pelaku bukan merupakan alternatif yang baik dalam memperbaiki kepribadian pelaku, sedangkan korban juga membutuhkan orang yang bertanggung jawab terhadap masa depan dan kehidupannya. Model kebijakan aparat yang menyerahkan penyelesaian masalah kepada orang tua pelaku dan orang tua korban merupakan suatu penyelesaian yang beraspek restorative justice. Penyelesaian perkara pada umumnya merupakan penerapan ganti rugi oleh pelaku dan keluarganya kepada korban atau keluarganya untuk menghindari konsekuensi balas dendam. Restorative justice mempunyai cara berfikir dan paradigma baru dalam memandang sebuah tindak kejahatan yang dilakukan oleh seorang manusia tanpa semata-mata memberikan hukuman pidana. Menurut pandangan konsep restorative justice penanganan kejahatan yang terjadi bukan hanya menjadi tanggung jawab negara akan tetapi juga merupakan tanggung jawab masyarakat. Oleh karena itu konsep restorative justice dibangun berdasarkan pengertian bahwa kejahatan yang telah menimbulkan kerugian harus dipulihkan kembali baik kerugian yang diderita oleh korban maupun kerugian yang ditanggung oleh masyarakat. ${ }^{8}$

Berdasarkan uraian pendahuluan tersebut diatas, maka yang menjadi permasalahan adalah bagaimana penerapan perlindungan hukum terhadap korban kekerasan seksual dalam rangka mewujudkan keadilan restoratif.

\section{Pembahasan}

\section{Perlindungan Hukum Terhadap Korban Kekerasan Seksual}

Di antara manusia Indonesia yang rawan menjadi korban kejahatan kekerasan adalah kaum perempuan. Kebijakan perlindungan merupakan salah satu bentuk kebijakan

\footnotetext{
${ }^{8}$ Marlina, 2010, Pengantar Konsep Diversi dan Restorative Justice dalam Hukum Pidana, Medan: USU Press, hal.38-40.

DOI : $\underline{\text { https://doi.org/10.30598/belovol6issue1page48-59 }}$ Copyright (c) 2020 Authors
} 
aplikasi yang dilakukan untuk melindungi korban. ${ }^{9}$ Beragam persoalan sensitif menimpa kehidupan kaum perempuan, antaranya kejahatan kekerasan seksual (sexual violence) dan pelecehan seksual (sexual harassment). Begitu banyak kejahatan kekerasan yang terjadi dan menimpa kaum perempuan, baik dalam soal pembunuhan, perkosaan, penganiayaan selain apa yang sudah disebutkan di atas. Perempuan sangat rentan menjadi korban kejahatan (victim of crime) di bidang kesusilaan. ${ }^{10}$

Undang-Undang No. 39 Tahun 1999 tentang Hak-Hak Asasi Manusia (HAM) khususnya Pasal 45 menyebutkan bahwa "Hak asasi perempuan adalah hak asasi manusia'. Dengan demikian karena hak asasi perempuan adalah hak asasi manusia, maka hak asasi perempuan ini harus dilindungi, dihormati, dipertahankan, dan tidak boleh diabaikan, dikurangi, atau dirampas oleh siapapun. Tindak kekerasan terhadap perempuan menjadi perhatian khusus. hal ini terlihat dari ditetapkannya sejumlah instrumen hukum internasional sebagai berikut:

1. Vienna Declaration and Prograame of Action (1993);

2. Convention on The Elimination of All Forms of Discrimination Against Women (1979);

3. Declaration on The Elimination of Violence Against Women (1993);

4. Beijing Declaration and Platform for Action (1995). ${ }^{11}$

Indonesia telah meratifikasi "Konvensi Penghapusan Segala Bentuk Diskriminasi Terhadap Perempuan” dengan Undang-Undang No. 7 Tahun 1984, dan membuat sebuah Undang- Undang yang diharapkan dapat menghapus semua tindak kekerasan yang terjadi terhadap perempuan di dalam lingkup rumah tangga yaitu UU No. 23 Tahun 2004 tentang Penghapusan Kekerasan Dalam Rumah Tangga (PKDRT), karena dirasakan

9 Lokollo, L., Salamor, Y. B., \& Ubwarin, E. (2020). Kebijakan Formulasi Undang-undang Narkotika Dalam Legalisasi Penggunaan Ganja Sebagai Bahan Pengobatan di Indonesia. Jurnal Belo , 5 (2) $1-10$.

${ }^{10}$ Marcheyla Sumera, Perbuatan Kekerasan/Pelecehan Seksual Terhadap Perempuan, Lex et Societatis, Vol. I/No.2/Apr-Jun/2013, hal.41

${ }^{11}$ Harkristuti Harkrisnowo, (2017) Hukum Pidana Dan Kekerasan Terhadap Perempuan, Bandung : Alumni, hal.79.

DOI : https://doi.org/10.30598/belovol6issue1page48-59 Copyright (c) 2020 Authors 
bahwa apa yang diatur dalam Kitab Undang-Undang Hukum Pidana (KUHP) belum mencukupi untuk mengeliminir bahkan menghapuskan tindak kekerasan yang terjadi terhadap perempuan.

Dalam KUHP ada beberapa perbuatan yang masuk kategori 'kekerasan/pelecehan seksual' yaitu:

- Merusak kesusilaan di depan umum (Pasal 281, 283, 283 bis);

- Perzinahan (Pasal 284);

- Pemerkosaan (Pasal 285);

- Pembunuhan (Pasal 338);

- Pencabulan (Pasal 289, 290, 292, 293 (1), 294, 295 (1).

Bentuk upaya perlindungan yang diberikan kepada korban kekerasan seksual adalah perlindungan yang diberikan oleh Undang-Undang-undang Nomor 13 Tahun 2006 tentang Perlindungan Saksi dan Korban juncto Undang-Undang Nomor 31 Tahun 2014 tentang perubahan atas Undang-Undang Nomor 13 Tahun 2006 tentang Perlindungan Saksi dan Korban, junctis Peraturan Pemerintah Nomor 44 Tahun 2008 tentang Pemberian Kompensasi, Restitusi, serta Bantuan Kepada Saksi dan Korban melalui Lembaga Perlindungan Saksi dan Korban. Bentuk-bentuk perlindungan tersebut meliputi: Restitusi, Bantuan Medis dan Bantuan Psiko-sosial.Sosialisasi hak-hak korban kepada korban kekerasan seksual harus ditingkatkan. Keadilan restoratif merupakan bentuk alternatif baru yang cocok diterapkan saat ini.

\section{Pentingnya Penerapan Keadilan Restoratif Terhadap Penyelesaian Tindak Pidana Kekerasan Seksual}

Penting berbicara tentang bagaimana meminta pertangungjawaban pelaku namun perlindungan korban juga penting. ${ }^{12}$ Secara umum pelaksanaan restorative justice memiliki prinsip-prinsip dasar sebagai berikut: ${ }^{13}$

12 Ubwarin, E., \& Corputty, P. (2020). Pertangungjawaban Pidana Dalam Keadaan Darurat Bencana Covid-19. Mizan: Jurnal Ilmu Hukum, Volume 9 Nomor 1, Juni 2020. hal 6.

DOI : https://doi.org/10.30598/belovol6issue1page48-59 Copyright (c) 2020 Authors 
a. keadilan yang dianut adalah adanya upaya pemulihan bagi pihak yang dirugikan;

b. siapapun yang terlibat dan terkena dampak dari tindak pidana harus mendapat kesempatan untuk berpartisipasi penuh dalam menindaklanjutinya;

c. Pemerintah berperan dalam menciptakan ketertiban umum, sementra masyarakat membangun dan memelihara perdamaian.

Mengacu pada prinsip-prinsip tersebut diatas terdapat empat nilai utama, yaitu:

a. Encounter (bertemu satu sama lain) yaitu menciptakan kesempatan kepada pihak-pihak yang terlibat dan mempunyai niat untuk melakukan pertemuan untuk membahas permasalahan yang telah terjadi dan pasca terjadi kejadian;

b. Amends (perbaikan) dimana sangat diperlukan pelaku mengambil langkah dalam memperbaiki kerugian yang terjadi akibat perbuatanya;

c. Reintegration (bergabung kembali kepada masyarakat) yaitu mencari langkah pemulihan para pihak secara keseluruhan untuk memberi kontribusi kepada masyarakat;

d. Inclusion (terbuka) dimana membuka kesempatan kepada semua pihak yang terkait untuk berpartisipasi dalam penanganannya.

Perhatian kepada pemulihan korban kekerasan seksual dan pemidanaan bagi pelakunya perlu sebanding dengan perhatian kita untuk mencegah peristiwa berulang. Tindakan yang diterima oleh korban bisa mengubah hidupnya secara drastis dengan berbagai dampak yang dialami antara lain stress yang berujung depresi, trauma, dan penyakit-penyakit lainnya hingga korban dapat mengakhiri hidupnya sendiri. ${ }^{14}$

Berdasarkan hal inilah maka mengapa konsep restorative justice mengandung pesan yang kuat tentang tanggung jawab semua pihak atas tindak pidana yang terjadi.

13 Ridwan Mansyur, (2010), Mediasi Penal Terhadap Perkara KDRT, Jakarta:Yayasan Gema Yustisisa Indonesia, hal.125

14 Mawati, E., Takariawan, A., \& Sulistiani, L. (2020). Kebijakan Hukum Pidana Mengenai Rehabilitasi Psikososial Korban Tindak Pidana Terorisme Dalam Sistem Peradilan Pidana. Jurnal Belo , 5 (2), 34-56

DOI : $\underline{\text { https://doi.org/10.30598/belovol6issue1page48-59 }}$ Copyright (c) 2020 Authors 
Dalam pendekatan keadilan restoratif memang dikenal atau penyelesaian dengan proses luar peradilan pidana yang kerap dipahamikan dengan "damai" dan "kekeluargaan". Dalam konteks keadilan restoratif, bukan untuk menghindarkan pelaku dari pertanggungjawaban hukum, melainkan menemukan model penyelesaian yang lebih esensial.

Penyelesaian dengan model ini juga memiliki berbagai persyaratan, termasuk wajib mengutamakan kepentingan korban dan harus memperoleh persetujuan dan kesepakatan dari korban dan keluarganya. Sehingga, pemaksaan, intimidasi maupun tekanan bagi keluarga dan korban untuk menyetujui dan menyepakati kesepakatan yang akan atau telah dibuat bersama tidak boleh ada. Pendampingan psikologis, medis dan hukum adalah suatu kesatuan serta peran serta masyarakat adalah penting.

Korban kekerasan seksual perlu mendapatkan perlindungan karena korban mengalami dampak yang sangat pelik. Dampak yang dirasakan oleh korban adalah penderitaan ganda yang meliputi penderitaan fisik, psikis, dan sosial. Penderitaan korban kekerasan seksual dialami pada saat pra persidangan, selama persidangan dan pasca persidangan. Oleh karenanya korban kekerasan seksual memerlukan perlindungan agar korban merasa aman dari segala bentuk ancaman dan untuk menjamin korban dalam usaha pemulihannya.

Segala bentuk kebijakan yang dilakukan oleh pemerintah sebagai bentuk pencegahan dan/atau bertujuan meminimalisir tindak kekerasan terhadap perempuan ternyata tidaklah mudah. Hal ini terlihat darPei banyaknya kasus pelecehan terhadap perempuan serta berbagai modus baru yang terjadi. Korban yang begitu dilindungi dengan berbagai peraturan hukum bahkan enggan untuk menempuh jalur hukum, akibat berbagai pertimbangan yang dirasakan baik oleh korban sendiri, keluarga, dan juga lingkungan tempat tinggalnya. 
Berbagai penerapan prinsip keadilan restoratif melalui proses perdamaian, penghentian penyidikan karena dicapainya kesepakatan, memberi bantuan biaya sekolah, tidak menahan pelaku anak, tetap melakukan penetapan tersangka, mempertimbangkan aspek tertentu untuk mediasi, menikahkan korban dengan pelaku, menitikberatkan ganti rugi, melakukan proses hukum namun tetap melindungi anak, penyelesaian perkara secara mediasi adat kekeluargaan.

Upaya lembaga perlindungan hukum atau lembaga advokasi dalam menciptakan penegakan hukum yang baik sangat membutuhkan faktor- faktor penunjang agar terciptanya perlindungan hukum tersebut dengan baik dan efektif. ${ }^{15}$ Upaya yang diutamakan dalam penegakan perlindunganterhadap korban kekerasan seksual ini adalah memperkuat, antara lain: pertama, faktor hukum; kedua, faktor penegak hukum; ketiga, faktor sarana dan fasilitas yang mendukung penegakan hukum; keempat, faktor masyarakat, kelima, faktor kebudayaan.

Hal ini menggambarkan bahwa kelima faktor tersebut harus saling berkesinambungan satu sama lain demi terciptanya penegakan perlindungan hukum yang efektif, karena apabila salah satu dari kelima faktor tersebut didapati tidak berjalan dengan baik dalam hal menjalankan tugasnya tersebut maka penegakan perlindungan hukum tidak akan berjalan efektif. Faktor penegak hukumlah yang dianggap sebagai patokan hukum oleh masyarakat luas, sehingga jika dalam faktor penegakan hukum ditemukan adanya keganjalan dalam menjalankan fungsi dan tugasnya tersebut, maka penegakan hukum yang diterapkan sudah pasti tidak akan berjalan efektif, dan tidak sesuai dengan isi dari undang-undang yang mengaturnya.

\section{Penutup}

Peradilan restoratif sebagai solusi alternatif dalam pengembalian keadilan tentu harus di upayakan. Pendekatan dengan pemberian keleluasan kedua belah pihak untuk

15 Anakotta, M. (2019). Kebijakan Sistem Penegakan Hukum Terhadap Penanggulangan Tindak Pidana Terorisme Melalui Pendekatan Integral. Jurnal Belo, 5(1), 46-66.

DOI : $\underline{\text { https://doi.org/10.30598/belovol6issue1page48-59 }}$ Copyright (c) 2020 Authors 
p-ISSN : 2460-6820 | e-ISSN : 2686-5920 Jurnal Belo Vol. 6 No. 1 Agustus 2020 - Januari 2021 | 58

berperan aktif dalam mencari solusi terbaik bagi mereka tentu akan berampak baik terhadap perkembangan metode pemidanaan yang selama ini dipandang belum bisa memberikan keadilan bagi masyarakat. Di samping itu, hendaknya para aparat penegak hukum (polisi, jaksa, hakim) beserta stakeholder terkait dalam memberi pelayanan dan perlindungan kepada perempuan korban perkosaan seyogyanya dilandasi dengan penuh empati dan rasa kemanusiaan.

\section{Daftar Pustaka}

\section{Jurnal}

[1] Anakotta, M. (2019). Kebijakan Sistem Penegakan Hukum Terhadap Penanggulangan Tindak Pidana Terorisme Melalui Pendekatan Integral. Jurnal Belo, 5(1), 46-66.DOI : https://doi.org/10.30598/belovol5issue1page46-66.

[2] Ayu Setyaningrum, R. A. (2019). Analisis Upaya Perlindungan dan Pemulihan Terhadap Korban Kekerasan dalam Rumah Tangga (KDRT) Khususnya AnakAnak dan Perempuan. Jurnal Ilmiah Muqoddimah : Jurnal Ilmu Sosial, Politik, dan Humaniora, 3 (1) 1-21. DOI : https://doi.org/10.31604/jim.v3i1.2019.9-19.

[3] Lokollo, L., Salamor, Y. B., \& Ubwarin, E. (2020). Kebijakan Formulasi Undang-undang Narkotika Dalam Legalisasi Penggunaan Ganja Sebagai Bahan Pengobatan di Indonesia. Jurnal Belo , 5 (2) 1-10.DOI : https://doi.org/10.30598/belovol5issue2page1-20.

[4] Mawati, E., Takariawan, A., \& Sulistiani, L. (2020). Kebijakan Hukum Pidana Mengenai Rehabilitasi Psikososial Korban Tindak Pidana Terorisme Dalam Sistem Peradilan Pidana. Jurnal Belo , 5 (2), $34-56$ DOI: https://doi.org/10.30598/belovol5issue2page34-56. 
p-ISSN : 2460-6820 | e-ISSN : 2686-5920 Jurnal Belo Vol. 6 No. 1 Agustus 2020 - Januari 2021 | 59

[5] Rochaety, N. (2014). Menegakkan Ham Melalui Perlindungan Hukum Bagi Perempuan Korban Kekerasan Di Indonesia. PALASTREN Jurnal Studi Gender, 7 (1) $1-24$.

[6] Sumirat, I. R. (2017). Perlindungan Hukum Terhadap Perempuan dan Anak Korban Kejahatan Perdagangan Manusia. Jurnal Studi Gender Dan Anak, 3(01), 19-30.

[7] Sumera, M. (2013). Perbuatan Kekerasan/Pelecehan Seksual Terhadap Perempuan. Lex et Societatis , 1 (2), 39-49.

[8] Ubwarin, E. (2019). Penegakan Hukum Terhadap Pelaku Penyelundupan Penyu Di Kabupaten Kepulauan Aru. RESAM Jurnal Hukum , 1-20.

[9] Ubwarin, E., \& Corputty, P. (2020). Pertangungjawaban Pidana Dalam Keadaan Darurat Bencana Covid-19. Mizan: Jurnal Ilmu Hukum , Volume 9 Nomor 1, Juni 2020. Hal 6. DOI : https://doi.org/10.32503/mizan.v9i1.1043

\section{Buku}

[10] Harkrisnowo, H. (2017). Hukum Pidana Dan Kekerasan Terhadap Perempuan. Bandung: Alumni.

[11] Kansil, C. (2014). Pokok-pokok Hukum Pidana. Jakarta: Pradnya Paramita.

[12] Mansyur, R. (2010). Mediasi Penal Terhadap Perkara KDRT. Jakarta: Yayasan Gema Yustisisa Indonesia.

[13] Marlina. (2010). Pengantar Konsep Diversi dan Restorative Justice dalam Hukum Pidana. Medan: USU Press.

[14] Perempuan, K. (2015). Bentuk Kekerasan Seksual Sebuah Pengenalan. Jakarta: Komnas Perempuan.

\section{Lain-lain}

[15] Ekawati,dkk, Pembentukan Kelompok Anti Kekerasan Seksual Anak (KAKSA) Pada Komunitas Kader di Desa Sanur Kaja Denpasar, diakses pada 20 Mei 2020.

DOI : https://doi.org/10.30598/belovol6issue1page48-59 Copyright (c) 2020 Authors 